\section{Yerel Yönetim Diplomasisi Özelinde Kardeş Şehir Uygulamasıyla İstanbul Örneği}

Town Twinning Implementation of Local Government Diplomacy

Particular to Istanbul

\section{İskender GÜNEŞ ${ }^{1}$ \\ Erdem EREN ${ }^{2}$}

Strategic Public Management Journal

Volume 7, Issue 13, pp. 35-59

May 2021

DOI: 10.25069/spmj.901822

Research Article/Araştırma Makalesi

Received: 23.03.2021

Accepted: 11.05.2021

(C) The Author(s) 2021

For reprints and permissions:

http://dergipark.gov.tr/spmj

$\ddot{O} z$

Küreselleşme süreciyle birlikte özellikle 20. yüzyllın ikinci yarısı itibariyle yerel yönetimler ve belediyeler diplomaside aktör olarak ön plana çıkmaya başlamıştır. Yerel yönetimlerin bu diplomatik faaliyetleri kamu diplomasisinin bir alt dalı olarak yerel yönetim diplomasisi adılla isimlendirilmiştir. Bu çalışmada ilk olarak yerel yönetim diplomasisi kavramı ana çerçevede ele alınmaktadır. Sonrasında ise yerel yönetim diplomasisi kavramı ve Türkiye'deki yerel yönetim diplomasisine dair hukuki altyapı tartışlmaktadır. Ayrıca kardeş şehir uygulaması ve İstanbul'daki belediyelerin kardeş şehir uygulamaları incelenmektedir. Çalışmada yerel yönetim diplomasisinin tam olarak ne olduğu, kardeş şehir uygulamasına neden ve nasıl başvurulması gerektiği ile İstanbul'daki belediyelerin kardeş şehir uygulamalarının çeşitlerine yönelik cevap aranmıştır. Sonuç olarak çalışmayla literatürde yerel yönetimlerin diplomatik girişimlerinin çok farklı şekillerde isimlendirildiği, sürdürülebilir ve işlevsel kardeş şehir ilişkilerinin kurulması için bazı etkenlerin olduğu görülmektedir. Bunun yanında Türkiye'deki yerel yönetim diplomasisi faaliyetleri için kanunlarla bir hukuki alt yapı oluşturulduğu, İstanbul belediyelerinin Türkiye'de yerel yönetim diplomasisinde en önemli aktörler olarak kültürel ve insani faaliyetler de dâhil birçok konuda öne çıktıkları görülmüştür.

Anahtar Kelimeler: Diplomasi, Kamu Diplomasisi, Yerel Yönetim Diplomasisi, Kardeş Şehir.

\begin{abstract}
Within globalization process local governments and municipalities have come to the fore as actors in diplomacy, especially in the second half of the 20th century. These diplomatic activities of local governments are named as local government diplomacy as a sub-branch of public diplomacy. In this study, firstly, the concept of local government diplomacy is discussed in the main framework. Later on the concept of local government diplomacy and legal infrastructure of local government diplomacy in Turkey have been discussed. In addition, the sister city implementation and the sister city practices of the municipalities in Istanbul are examined. In the study, an answer was sought for exactly what local government diplomacy is, why and how to apply the sister city implementation and the types of sister city practices of the municipalities in Istanbul. As

\footnotetext{
${ }^{1}$ Dr., Marmara Üniversitesi, Mahalli İdareler ve Yerinden Yönetim Bölümü Mezunu, iskender34gunes@gmail.com; ORCID ID: 0000-0003-4829-3220.

${ }^{2}$ Doktora Programı Öğrencisi, İstanbul Yeni Yüzyıl Üniversitesi Sosyal Bilimler Enstitüsü, Siyaset Bilimi ve Uluslararası İlişkiler Bölümü, erdemeren2234@gmail.com, ORCID ID: 0000-0002-9891-1763.
} 
a result, it is seen that the diplomatic initiatives of local governments are named in many different ways in the literature and there are some factors for the establishment of sustainable and functional sister city relations. Besides, a legal infrastructure was created for local government diplomacy activities by law in Turkey, municipalities in local government diplomacy in Turkey were found as the most important actors to come forward especially with cultural and humanitarian activities.

Key Words: Diplomacy, Public Diplomacy, Local Government Diplomacy, Town Twinning.

\section{GíRiş}

Küreselleşme ve geleneksel diplomasi metodu olan devletlerarası ilişkilerin giderek sıradanlaşması ve etkisizleşmesiyle diplomasi de başta uluslararası örgütler, çok uluslu şirketler, sivil toplum kuruluşları, baskı grupları vb. aktörler ön plana çıkmaya başlamış kamu diplomasisi olarak adlandırılan bu yeni diplomasi türünde yerel yönetimler de önemli birer aktörler olarak yer almaya başlamışlardır (Eren, 2017, s. 46-48). Yerel yönetimlerin ve özellikle belediyelerin yurt dışındaki belediyelerle kurmuş oldukları uluslararası ilişkiler faaliyetleri ise yerel yönetim diplomasisi ve/veya yerel diplomasi vb. isimlerle nitelendirilmiştir.

$\mathrm{Bu}$ çalışmada kamu diplomasisinin bir alt dalı olarak sayılan yerel yönetimlerin diplomaside aktör olarak ele alındığı yerel yönetim diplomasisi ana çerçevede incelenecek olup, yerel yönetim diplomasisi özelinde ise en çok başvurulan uygulamalardan biri olan kardeş şehir uygulaması ve İstanbul'daki belediyelerin bu kapsamdaki ilişkilerine değinilecektir. Çalışmanın ilk bölümünde kavramsal olarak yerel yönetim diplomasisi, yerel yönetimlerin diplomaside aktör oluş süreçleri ve kavramla eş anlamda kullanılan yerel diplomasi, kent diplomasisi vb. kavramlarla birlikte açıklanacaktır. İkinci bölümde ise yerel yönetim diplomasisi uygulamalarının Türkiye'deki hukuksal altyapısı mevzuat ve kanunlar üzerinden incelenecektir. Üçüncü bölümde ise yerel yönetim diplomasisinin en önemli uygulamalarından biri olan kardeş şehir uygulamasının ne olduğu ve Türkiye' de nasıl geliştirilmeye çalışıldığı, buna ek olarak İstanbul örneğinde İstanbul Büyükşehir Belediyesi ile ilçe belediyelerinin ne gibi ilişkilerinin mevcut olduğuna yönelik istatistikî veriler ve örnekler verilmiştir.

\section{KAVRAMSAL OLARAK YEREL YÖNETIM DIPLOMASISİ}

Diplomasi kelimesi başlangıçta belgeleri gözden geçirme bilimi olarak ortaya çıkmakla beraber etimolojik olarak ikiye katlama anlamına gelmektedir. Bu terim ilk kez 1796'da İrlanda doğumlu İngiliz devlet adamı ve seçkin siyasi düşünür Edmund Burke tarafından kullanılmıştır (Berridge, James, 2003, s. 70). Rogier van der Pluijm'a göre; "Yabancı bir ülkenin başkentinde ikamet eden daimi misyonların kurulması ile karakterize edilen modern diplomasinin kökenini Vestfalya Barışı'nda bulduğu sıklıkla iddia edilmektedir”. Plujm aynı zamanda diplomasinin temellerinin 1648 'den çok daha önce, günümüzdeki devletlerin henüz tarih sahnesinde olmadıkları ve şehirlerin dış politikaya yön verdikleri zamanlarda kurulduğunu belirtmektedir. Dolayısıyla diplomasinin varlığının devletlerin varlığından da önce bulunduğu gerçeği karşımızda durmaktadır (Pluijm \& Melissen, 2007).

Egemen devletler arasındaki ilişkilerin kendi devletlerinin diplomatik hizmetinin üyesi ya da geçici diplomatları aracılığıyla yurtiçinde veya yurtdışında yürütülmesi olarak ifade edilen diplomasi, uluslararası kuruluşlarda temsilcilerin konuşlandırılmasını da içermektedir (Berridge, James, 2001, s. 62). Devletlerin hak ve menfaatlerinin korunması ve savunulmasının yanısıra bu maksatla: devletler ve milletlerarası kurullar 
çerçevesinde temsile sahip olması, anlaşmalar imzalanması veya anlaşmazlıkların halledilmesi diplomasinin temel noktalarını oluşturmaktadır (Birgi, 1983, s. 37).

1990’lı yıllarla birlikte uluslararası ilişkilerde devletlerin diplomasideki rolünün yanında devlet dışı aktörlerin de önemi ve etkisi giderek artmaya başlamıştır. Bu bağlamda; uluslararası örgütler, çokuluslu şirketler ve sivil toplum kuruluşları küresel siyasette yükselen yıldızlar olarak öne çıkmışlardır. Literatürde genel olarak unutulan bir diğer önemli aktör ise belediyelerdir (Demirtaş, 2016, s. 152). Belediyelerde son yıllarda diğer devlet dışı aktörlerin yanında gerçekleştirdikleri dış ilişkiler faaliyetleriyle diplomasi de etkin olmaya başlamışlardır. James N. Rosenau, 21. yüzyılda küresel siyaseti analiz ettiği makalesinde küresel yönetişimin giderek daha fazla parçalandığını ve devletlerin de bu noktada hâkim rollerini kaybetmeye başladıklarını vurgulamış, bu süreçte ulus ötesi yönetişim ile ulus altı yönetişimin kendini gösterdiğini ifade etmiştir. Rosenau sivil toplum kuruluşlarını ulusların sınırını aşan ulus ötesi yönetişim olarak sınıflandırırken; ulus altı yönetişim örneği olarak da kentlerin ve mikro bölgelerin uluslararası ilişkilerde aktifleşmeye başladıklarını dile getirmiştir. Ayrıca; "kentlerin ve mikro bölgelerin yirmi birinci yüzyılın dünya politikasında önemli merkezi mekanizmalar olabileceğini” öne sürmüştür (Rosenau, 1995, s. 13-43).

Ulusal dış politikaya aykırı olmamak ve hukuken belirlenen sınırlara tabi kalarak yerel yönetimlerin uluslararası alanda gerçekleştirdiği her türlü faaliyet yerel yönetimlerin uluslararası faaliyetleri olarak tanımlanmakta olup, yerel yönetimler bu faaliyetleriyle kamu yararının sağlanmasını amaçlamaktadır (Özlü, 2020, s. 161). Literatürde günümüze kadar yerel yönetimlerin dış ilişkiler faaliyetlerini yani dünyayla ilişkileri tanımlamak için kullanılan en genel tabir "yerel diplomasi”" olsa da; "paradiplomasi, ulus-altı dış politika, yerel dış politika, belediyelerin dış politikası, kent/şehir diplomasisi ve mikro bölgesellik" gibi kavramlar da en çok kullanılan kavramlar olmuşlardır (Demirtaş, 2016, s. 154).

İlk olarak paradiplomasi; literatürde paralel diplomasi kavramının kısaltılması amacıyla kullanılmakta olup, yerelin merkezin dış ilişkiler faaliyetlerine paralel olarak merkezin dış politikasını kendi araçlarını kullanarak takip ettiğini varsaymaktadır (Aguirre, 1999, s. 185-209). Paradiplomasi ile yerel yönetimler merkezi yönetimlerin ulusal dış politikalarını destekleyici faaliyetlerde bulunarak ulusal çıkarlarını belirli platformlarda savunma amacıyla da uluslararası ilişki geliştirebilmektedir (Baş, 2017, s. 32). Bu amaçları gerçekleştirmek için yerel yönetimler; ekonomik ve finansal ortaklıklar; kültürel, eğitsel, teknolojik vb. alanlardaki işbirlikleriyle diplomatik ilişkiler olmak üzere üç kademede faaliyette bulunmaktadır (Yaylı ve Gönültaş, 2018, s. 280-282).

Yerel yönetimlerin uluslararası boyuttaki işbirliği ve stratejilerini açıklamak için en yoğun kullanılan deyimlerden biri de yerel dış politika deyimidir. Örneğin; Amerika Birleşik Devletleri’nde yerel yönetimlerin uluslararası girişimlerini anlatırken en çok tercih edilen deyimler "local foreign policy" yani yerel dış politika ile "subnational foreign policy" yani ulus altı dış politika'dır (Daoudov, 2013, s. 28-29). Ulus altı dış politika ile yerel dış politika kavramları genel olarak merkezi yönetimin altında kalan tüm birimlerin dış ilişsilerini faaliyetlerini kapsamaktadır (Mcmillan, 2008, s. 232-237). Yerel düzeyde ülkeler arası ilişkilerin yereller arası ilişkiye dönüştüğü ve yerelin ulus üstü yani merkezi politikaya müdahil olabildiği küreselleşme döenminde farklı ülkelerle iletişime geçmekte olduğu süreçte "ulus altı politikadan" söz edilebilmektedir (Yaylı ve Gönültaş, 2018, s. 279). 
Belediyelerin dış politikası ise yerel yönetimlerin ve belediyelerin dış dünyayla ilişkilerini tanımlamaktadır. Belediyelerin dış politikası çok aktörlü ve çok yönlü uluslararası diplomasiye katkı sağladığı gibi, yerel yönetimlerin dünyadaki diğer birimlerle olan ilişkilerini de önemli derecede etkilemektedir (Daoudov, 2013, s. 5; 27-28). Son olarak kent/şehir diplomasisi kavramı da kentlerin küresel siyasette kendilerini temsil etmek ve çıkarlarını gerçekleştirmek amacıyla uyguladıkları politikayı ifade etmektedir (Pluijm \& Melissen, 2007, s. 6). Kent/şehir diplomasisi; yerel yönetimleri, kurumlarını ve çıkarlarını temsil etmek amacıyla uluslararası siyasi alandaki aktörlerle temas eden konuma getiren kurum ve süreçlerdir. Bu diplomasi türü altı başlık halinde incelenmekte olup bunlar; güvenlik, kültür, ekonomi, kalkınma, ağ oluşturma ve temsildir (Gençkaya ve Kaya, 2018, s. 305).

Türkiye'deki literatür çalışmalarında yerel yönetimlerin dış ilişkiler faaliyetlerini tanımlamak için kullanılan iki kavram öne çıkmaktadır. Bunlar; yerel diplomasi ve belediyelerin dış politikası kavramları olup bu iki kavram da bünyesinde eksiklikler taşımaktadır. İlk olarak yerel diplomasi kavramı her ne kadar yerel yönetim diplomasisi kavramının kısaltması olsa da "yerel" ve "diplomasi (küresel bir terim)" birbirine tezat iki kavramı ifade ettiği için anlamı bozmaktadır. İkinci olarak belediyelerin dış politikası kavramı yerine doğru ifade belediyelerin diplomasisi olsa da, sadece belediyelerin değil, belediye birliklerinin de diplomasi faaliyetlerinde bulunduğunu göz önüne almayı gerektirmektedir. Bu nedenle bu çalışma da daha kapsayıcı olmasından dolayı "yerel yönetim diplomasisi” kavramı tercih edilecektir.

Günümüzde yerel yönetimlerin diplomasi faaliyetlerinde etkili olmasını sağlayan bazı yapısal unsurlar bulunmaktadır. Bunlar;

$\checkmark$ Belediyelerin dış ilişkiler bağlamında hangi çerçevede hareket edeceğini belirleyen ülkenin idari yapısı ve yasal çerçevesi,

$\checkmark$ Kentin tarihsel altyapisi,

$\checkmark$ Kentin coğrafi konumu (dış ülkelere yakınlığı ve uzaklığı),

$\checkmark$ Kentin demografik yapısı (göçmen nüfusun varlığı),

$\checkmark$ Merkezi devletin küresel siyaset anlayışı,

$\checkmark$ Yerelin maddi imkânları,

$\checkmark$ Belediye başkanının dış ilişkilere olan ilgisi ve tecrübesidir (Demirtaş, 2016, s. 155-156).

Yerel yönetimlerin diplomasi faaliyetlerine girişmesinin bir takım nedenleri bulunmakta olup bunlar özetle; ekonomik, kültürel, barış, insani yardımlar, temsil, markalaşmadır. İlk olarak küreselleşen dünyada ulus devletler gibi kentler de ekonomik olarak bir yarış içerisinde olup ekonomik anlamda güçlenmeye çalışmaktadır. İkinci olarak belediyeler başta kardeş şehir ilişkileri ve çeşitli işbirlikleriyle kültürlerinin tanıtılmasına çaba sarf etmektedir. Üçüncü olarak özellikle Türkiye belediyeleri yurt içi ve yurt dışında diğer ülkelerle işbirliği de kurarak Ramazan faaliyetleri, ülke günleri ve sergileri, çeşitli deprem, doğal afet vb. kriz dönemlerinde yaptıkları yardım faaliyetleriyle hem kültürel hem de insani yardım noktasında hizmet gütmektedir. Son olarak belediyeler ülkeler arasındaki diplomatik ilişkileri geliştirerek barışa da katkı sunmaktadır (Demirtaş, 2016, s. 156-157).

Yerel yönetim diplomasisi tarihini incelendiğinde; yerel birimlerin küresel düzeyde ilk örgütlenmesinin 1973 yılında kurulan "Uluslararası Belediye Hareketi - International Municipal Movement (UBH)" olduğu görülmektedir. Bu Hareket misyonunu daha sonra 2004 yılında "Birleşmiş Kentler ve Yerel Yönetimler United Cities and Local Governments (UCLG)" kuruluşuna bırakmıştır. Merkezi Barselona'da olan ve 140 ülkeden 240.000 yerel yönetimin yanı sıra 175 yerel birliği kapsamakta olan UCLG'nin hâlihazırda temel amacı 
ekonomi ve siyasettir. Öte yandan kuruluş; yerel düzeyde kalkınma ve inovasyonu, yerel ve bölgesel birimlerin küresel yönetişimde seslerini daha fazla duyurmaları, dünya barışına katkı sunmayı da hedeflemektedir. Kuruluşun Orta Doğu ve Batı Asya Bölge Teşkilatının merkezi de İstanbul'da bulunmaktadır (UCLG, s. 2020).

Günümüzde uluslararası engelleri aşmak ve sunulan hizmetleri yaygınlaştırmak üzere şehirler küresel ölçekli ağlarda birlikte hareket etme yolunu seçmişlerdir. $\mathrm{Bu}$ yapılar arasında etkili duruş sergileyen oluşumlar arasinda;

$\checkmark$ Uluslararası Şehir Yöneticileri (City Leaders),

$\checkmark$ Dünya Belediye Başkanları Forumu (Global Mayors Forum),

$\checkmark$ Uluslararası Şehir/Belde Yönetimleri Derneği (ICMA),

$\checkmark$ Küresel Kardeş Kentler (Sister Cities),

$\checkmark$ Dünya Büyük Büyükşehirler Birliği (Metropolis),

$\checkmark$ İslami Başşehirleri ve Şehirleri Teşkilatı (OICC),

$\checkmark$ Türk Dünyası Belediyeler Birliği (TDBB),

$\checkmark$ Asya Belediye Başkanları Forumu (Asian Mayors),

$\checkmark$ Güçlü Şehirler Ağı (Strong Cities Network),

$\checkmark$ Kentler İttifakı (Cities Alliance),

$\checkmark$ Akıllı Dünya Kentleri (World Smart City),

$\checkmark$ C40 İklim Liderliği Kenti Grubu,

$\checkmark$ EUROCITIES,

$\checkmark$ Cittaslow,

$\checkmark$ Dünya Miras Şehirleri (OWHC),

$\checkmark$ Avrupa Belediyeler ve Bölgeler Konseyi (CEMR),

$\checkmark$ Avrupa Konseyi Yerel ve Bölgesel Yönetimler Kongresi (KONGRE),

$\checkmark$ Avrupa Birliği Bölgeler Komitesi (COR),

$\checkmark$ Avrupa Bölgeleri Meclisi (AER),

$\checkmark$ Avrupa-Akdeniz Bölgesel ve Yerel Meclisi (ARLEM),

$\checkmark$ Güney-Doğu Avrupa Yerel Yönetim Birlikleri Ağı (NALAS) gibi kurumlar ön plana çıkmaktadır.

Şehirlerin ve belediye başkanlarının bölgesel ölçekte kurmuş oldukları farklı federasyonlar ve birlikler de şehirlerinin gelecek ile ilgili planlarına önemli katkılar sunmaktadırlar. Son on yılda, birçok alanda şehirlerarası ağlar kurulmuş ve işbirlikleri geliştirilmiştir. Bu süreçte şehirler kendilerinin sunmakta oldukları hizmetlerle ilgili konularda yetkilerinin genişletilmesini küresel ölçekte arzu etmektedirler. Bu sürece katkı sağlamak amacıyla 2016 yılı Eylül'ünde Hollanda'da Küresel Belediye Başkanları Parlamentosu (Global Parliament of Mayors) kurulmuştur (GPM, 2021). Uluslararası sınırlar boyunca güvenlik ve refahı artırmak için yeniden yapılanmayı teşvik etmek için Barış İçin Belediye Başkanları, Barış İçin Şehirler ve Ortadoğu'da Barış İçin 
Belediye İttifakı gibi oluşumlar da şehirlerin birlikte çalışmalarının önemli bir bileşeni olarak kendi alanlarında faaliyetler sürdürmektedir ${ }^{3}$.

Türkiye'deki yerel yönetimler de uluslararası muadilleri ile yarışacak bir seviyeye ulaşmıştır. Bunun neticesi olarak yerel yönetimler açısından ağırlığı ve önemi olan uluslararası ve bölgesel anlamda yerel yönetimleri ilgiliendiren birçok kuruluşa üyelik ve katılım gösterdikleri gözlenmektedir. Türkiye Cumhuriyeti Çevre ve Şehircilik Bakanlığı Yerel Yönetimler Genel Müdürlügünün konu ile ilgili verdiği bilgiye göre Türkiye'deki yerel yönetimlerin üyesi olduğu 127 adet uluslararası kuruluş bulunmaktadır. Bu kuruluşlara ve üye olan Türk yerel yönetimlerine dair tablo şu şekildedir;

Tablo 1: Türkiye'deki Belediyelerin Uluslararası Kuruluş Üyelikleri

Akdeniz Kentler Birliği; Antalya, Gaziantep, İzmir ve Mersin Büyükşehir Belediyesi

Akıllı Ulaşım Sistemleri Derneği; Gaziantep Büyükşehir Belediyesi

Arap Kentleri Teşkilatı; Marmara Belediyeler Birliği

Asya Pasifik Bilim ve Teknoloji Merkezleri Ağı; Bursa Büyükşehir Belediyesi

Avrupa Belediyeler ve Bölgeler Konseyi; Vilayetler Hizmet Birliği, Trabzon Büyükşehir Belediyesi

Avrupa Birliği Araştırma ve İnovasyon Ağı; Gaziantep ve Ankara Büyükşehir Belediyesi

Avrupa Bölgeler Meclisi; Adana, Antalya, İstanbul ve İzmir Büyükşehir Belediyesi

Avrupa Engelli Hizmet Sağlayıcıları Derneği; Kadıköy Belediyesi

Avrupa Entegrasyonunun Desteklenmesi Programı; Türkiye Belediyeler Birliği

Avrupa Gastronomi Mirası; Gaziantep Büyükşehir Belediyesi

Avrupa Hayvanat Bahçeleri ve Akvaryumlar Birliği; Bursa ve İzmir Büyükşehir Belediyesi

Avrupa Irkçılık Karşıtı Kentler A ğı; Kadıköy Belediyesi

Avrupa Kentler Ağı; Gaziantep Büyükşehir Belediyesi

Avrupa Tarihi Kentler Birliği (Avrupa Tarihi Kasabalar ve Bölgeler Derneği); Tarihi Kentler Birliği, Bursa BŞB, Denizli Pamukkale, İzmir Birgi, Mersin Tarsus ve Tokat Niksar Belediyesi

Avrupa Leylek Köyleri Ağı Belediyeler Birliği; Bursa Karacabey Belediyesi

Avrupa Konseyi Parlementerler Meclisi Sağlık ve Sürdürülebilir Kalkınma Komisyonu Tarafından Verilen Avrupa Ödülü; İzmir Konak Belediyesi

Avrupa Ödülü Kazanan Kentler Birliği; Ankara Büyükşehir Belediyesi

Avrupa Yerel Demokrasi Ajansları Derneği; Karşıyaka Belediyesi

Avrupa Yerel ve Bölgesel Yönetimler Eğitim Kurumları İletişim Ağı; Türkiye Belediyeler Birliği

Avrupa Yerel Yönetimler Ağı; İzmir Büyükşehir Belediyesi

\footnotetext{
${ }^{3}$ Detaylı Bilgi İçin Bkz. Mayors For Peace, http://www.mayorsforpeace.org/; International Cities of Peace, http://www.internationalcitiesofpeace.org/, United Nations Development Programme-Programme of Assistance to the Palestinian People, The Municipal Alliance for Peace in the Middle East (MAP) is Launched in Jerusalem, http://www.undp.ps/en/newsroom/pressreleasespdf/2005/12eb.pdf.
} 
Avrupa-Akdeniz Bölgeler ve Yerel Yönetimler Kongresi; Gaziantep Büyükşehir Belediyesi

Avrupa-Akdeniz Yerel ve Bölgesel Otoriteleri Daimi Komitesi; Zonguldak Karadeniz Ereğli Belediyesi

Avrupa-Akdeniz Kültür Şehirleri Birliği; Mersin Büyükşehir Belediyesi

Akdeniz Yerel Yönetimler İşbirliği Programı; Türkiye Belediyeler Birliği, Bodrum Belediyesi

Alman Su, Atık Su ve Katı Atık Birliği; Türkiye Belediyeler Birliği

Asya Belediye Başkanları Forumu; Ankara, Antalya, Diyarbakır, Gaziantep ve Mersin Büyükşehir Belediyesi

Avrupa Akdeniz Zirvesi; Ankara Büyükşehir Belediyesi

Avrupa Bölgeler Asamblesi; Gaziantep Büyükşehir Belediyesi

Avrupa Bilim Merkezleri ve Müzeleri Ağı; Bursa Büyükşehir Belediyesi, Bursa Büyükşsehir Kent Müzesi

Avrupa Birliği Belediye Başkanları Sözleşmesi; Bolu ve Bursa Büyükşehir Belediyesi, Karşıyaka Belediyesi

Avrupa Engelsiz Turizm Ağı; İzmir Büyükşehir Belediyesi

Avrupa Festivaller Birliği; Antalya Büyükşehir Belediyesi

Avrupa Gençlik Başkenti; Trabzon Büyükşehir Belediyesi

Avrupa Irkçılığa Karşı Şehirlerin Koalisyonu; İzmir Konak Belediyesi

Avrupa Kalkınma Ajansları Birliği; Yeşilırmak Havzası Kalkınma Birliği

Avrupa Living Lab Ağı; İstanbul Büyükşehir Belediyesi

Avrupa Marka Kentler Birliği; Bursa Büyükşehir Belediyesi

Avrupa Kentler Birliği; Bursa Büyükşehir Belediyesi, Bursa Nilüfer, İstanbul Büyükşehir Belediyesi, Beşiktaş, Beylikdüzü, Beyoğlu, Kadıköy, Beşiktaş, Beylikdüzü, Beyoğlu, Kadıköy, Pendik, İzmir Büyükşehir Belediyesi, Karşıyaka, Selçuk, Mersin Mezitli, Muş Merkez Belediyesi

Avrupa Konseyi Yerel ve Bölgesel Yönetimler Kongresi; Marmara Belediyeler Birliği

Avrupa Sosyal Hizmet Ağı; İstanbul Büyükşehir Belediyesi

Avrupa Yerel Demokrasi Birliği; Balıkesir Edremit Belediyesi

Avrupa Tarihi Kentler ve Bölgeler Birliği; Nevşehir Ortahisar Belediyesi

Avrupalı Bilim Merkezleri ve Müzeler Ağı; Gaziantep Büyükşehir Belediyesi

Avrupa Yerel Yaşamda Kadın Erkek Eşitliği Sözleșmesi; Tunceli Belediyesi

Avrupa-Akdeniz Yerel ve Bölgesel Otoriteleri Daimi Komitesi; Düzce Merkez Belediyesi

Avrupalı Seçkin Turist Destinasyonu; Gaziantep Büyükşehir Belediyesi, Ankara Altındağ Belediyesi

Balkan Ülkeleri Kardeş Şehirler Birliği; Bursa Büyükşehir Belediyesi

Barış İçin Yerel Yönetimler Birliği; Nevşehir Merkez Belediyesi

Belediye Başkanları Sözleşmesi; Antalya Büyükşehir Belediyesi

Bölgesel Mutfak Mirası İşbirliği Ă̆ı; Antalya Alanya Belediyesi

Barış İçin Belediye Başkanları Sözleşmesi; İstanbul Beşiktaş Belediyesi

Barış İnsiyatifi Birliği; Konya Büyükşehir Belediyesi 
Büyük Balkan Kentleri Teşkilatı; Ankara Büyükşehir Belediyesi

Delice-Dünya İyi Yemek Ağı; Gaziantep Büyükşehir Belediyesi

Deprem ve Megakentler Girişimi; İstanbul Büyükşehir Belediyesi

Dünya Birleşik Kentler Federasyonu; Afyonkarahisar Merkez, Türkiye Belediyeler Birliği, Akdeniz Belediyeler Birliği, Çorum Merkez, Edirne Merkez Belediyesi, Erzurum ve Eskişehir Büyükșehir Belediyesi, Kırşehir Merkez, Manisa Merkez, Mardin Merkez, Muğla Merkez, Samsun Ondokuz Mayıs, Tekirdağ Merkez, Karadeniz Ereğli Belediyesi

Dünya Büyük Metropoller Birliği; Diyarbakır, Gaziantep ve İstanbul Büyükşehir Belediyesi

Dünya Büyükşehirler Zirve Konferansı; İstanbul Büyükşehir Belediyesi

Dünya E-Devletler Organizasyonu; Gaziantep, Malatya ve Muğla Büyükşehir Belediyesi

Dünya Gurme Kentler Birliği; İzmir Büyükşehir Belediyesi

Dünya Haller Birliği; Amasya Merkez Belediyesi, Ankara, Antalya, Bursa, İstanbul ve İzmir Büyükşehir Belediyesi

Dünya İdari Kentler Birliği; Ankara Büyükşehir Belediyesi

Dünya Kaleli Kentler Birliği; Antalya Alanya Belediyesi, Bursa ve Diyarbakır Büyükşehir Belediyesi, Niksar, Karadeniz Ereğli Belediyesi

Dünya Kentler ve Yerel Yönetimlerin E-Yönetimleri Teşkilatı; Ankara Büyükşehir Belediyesi

Dünya Mirası Şehirleri Teşkilatı; Bursa ve Konya Büyükşsehir Belediyesi

Dünya Sağlık Örgütü Küresel Yaş Dostu Kentler Ağı; Ankara Büyükşehir Belediyesi

Dünya Mirası Şehirleri Teşkilatı (Dünya Tarihi Kentler Birliği); İstanbul Büyükşehir Belediyesi

Dünya Tarihi Kentler Birliği; Ankara ve Bursa Büyükşehir Belediyesi

Dünya Sağlık Örgütü Avrupa Sağlıklı Şehirler Ağı; İstanbul, İzmir ve Kocaeli Büyükşehir Belediyesi, Mezitli Yalova Merkez, Sandıklı, Çankaya, Burdur Merkez, Bursa Büyükşehir Belediyesi, Nilüfer, Bursa Sağlıklı Kentler Birliği, Denizli Büyükşehir Belediyesi, İstanbul Kadıköy, Balçova, Karşıyaka, Gölcük, Trabzon Büyükşehir Belediyesi

Dünya Ulaştırma Konferansı Derneği; İstanbul Büyükşehir Belediyesi

Enerji Geleceğine Yatırım Yapan Avrupa Yerel Yönetimler Ağı; İzmir Gaziemir Belediyesi

Enerji Kentleri Gaziantep Büyükşehir; İzmir Urla, Bursa Nilüfer, İstanbul Büyükçekmece, İstanbul Kadıköy, Gaziantep Büyükşehir Belediyesi

Folklor Festivalleri ve Halk Sanatları Kuruluşları Uluslararası Konseyi; Karşıyaka, Kocaeli Büyükşehir Belediyesi

Geri Dönüşüm İçin Şehirler Birliği; Bursa Büyükşehir Belediyesi

Glukalizasyon Konferansı; Ankara Büyükşehir Belediyesi

Gökkuşağı Şehirler Ağı; İstanbul Beşiktaş Belediyesi

Uluslararası Kütüphane Dernekleri ve Kurumları Federasyonu; Bursa Büyükşehir Belediyesi

Uluslararası Müzeler Birliği; Eskişehir Büyükşehir Belediyesi

Uluslararası Müzeler Konseyi; Bursa Büyükşehir Belediyesi

Uluslararası Ormanlar İçin Şehirler Birliği; Antalya Büyükşehir Belediyesi 
Uluslararası Park ve Rekreasyon Yönetim Federasyonu; Gaziantep Büyükşehir Belediyesi

Uluslararası Planetaryum Platformu; Bursa Büyükşehir Belediyesi

Uluslararası Rotta Di Enea Derneği; Çanakkale Merkez Belediyesi

Uluslararası Sakin Şehirler Birliği; Aydın Yenipazar, Bolu Göynük, Mudurnu, Çanakkale Küçükkuyu, Erzurum Uzundere, İzmir Seferihisar, Urla, Kırklareli Merkez Muğla Akkaya ve Ula Belediyesi

Uluslararası Spor ve Kültür Derneği; İzmir Karşıyaka Belediyesi

Uluslararası Su Kaynakları Birliği; Adıyaman Merkez Belediyesi

Uluslararası Şehir Aydınlatma Birliği; İstanbul Büyükşehir Belediyesi

Uluslararası Tarım Şehirleri Birliği; Bursa Büyükşehir Belediyesi

Uluslararası Tarihi Ev Müzeleri Komitesi; İstanbul Büyükşehir Belediyesi

Uluslararası Toplu Taşımacılar Birliği; Edirne Belediyesi, Gaziantep, İzmir, Kahramanmaraş ve Kocaeli Büyükşehir Belediyesi

Güneydoğu Avrupa Yerel Yönetimler ve Birlikler Ă̆ı; Türkiye Belediyeler Birliği, Marmara ve Boğazları Belediyeler Birliği

Güvenli Toplum Ağı; Bursa Nilüfer Belediyesi

Hareketli Şehirler Ağı; Antalya Büyükşehir Belediyesi

Internatıonal Sports and Culture Association; İzmir Konak Belediyesi

İklim ve Enerji İçin Belediye Başkanları Sözleşmesi; Kocaeli ve Sakarya Büyükşehir Belediyesi

İktisadi İşbirliği Kalkınma Teşkilatı; İstanbul Büyükşehir Belediyesi

İpekyolu Belediye Başkanları Forumu; Gaziantep Büyükşehir Belediyesi

İslam Başkentleri ve Kentleri Teşkilatı; Ankara ve Gaziantep Büyükşehir Belediyesi, Marmara Belediyeler Birliği

İslam Konferansı Diyalog ve İşbirliği Gençlik Forumu; İstanbul Büyükşehir Belediyesi

Kaleli Kentler Birliği; Gaziantep Büyükşehir Belediyesi

Karadeniz Başkentleri Birliği Teşkilatı; Ankara Büyükşehir Belediyesi

Kentsel Gelişme Küresel Fonu; Nilüfer, İstanbul Büyükşehir Belediyesi

Kuzey Afrika ve Orta Doğu Bilim Merkezleri Ă̆ı; Bursa Büyükşehir Belediyesi

Kültür için Avrupalı Kentler ve Bölgeler Ă̆ı; İzmir Urla Belediyesi

Küresel Belediyeler Göstergeleri Ă̆gı; İstanbul Büyükşehir Belediyesi

Küresel Şehirler Diyaloğu; Yalova Merkez Belediyesi

Küresel Tasarım Şehirleri Organizasyonu; Ankara ve İstanbul Büyükşehir Belediyesi

Milletlerarası Müzeler Konseyi; Bursa ve İstanbul Büyükşehir Belediyesi

Sürdürülebilirlik İçin Dünya Yerel Yönetimler Birliği; Ankara, İzmir ve Gaziantep Büyükşehir Belediyesi, Çankaya, Eskişehir Tepebaşı, Karşıyaka, Rize Fındıklı Belediyesi

Şehirlerarası Manevi Kültürel İşbirliği Ağı; Nevşehir Merkez Belediyesi

Telecities; Yalova Merkez Belediyesi 
Türk Dünyası Belediyeler Birliği; Ankara, Gaziantep, İstanbul ve Kocaeli Büyükşehir Belediyesi, Afyonkarahisar Merkez, Ankara Altındağ, Karabük Safranbolu, Konya Selçuklu Belediyesi

Uluslararası Aeneas Rotası Derneği; Balıkesir Edremit Belediyesi

Uluslararası Botanik Bahçeleri Koruma Birliği; Gaziantep Büyükşehir Belediyesi

Uluslararası Film Üreticileri Birliği Federasyonu; Antalya Büyükşehir Belediyesi

Uluslararası Folklor Fesivalleri ve Geleneksel Sanatlar Organizasyon Konseyi; Gaziantep Büyükşehir Belediyesi

Uluslararası Yerel Çevre Girişimleri Konseyi; İstanbul Kadıköy, Kartal, İzmir Büyükşehir Belediyesi, Seferihisar Belediyesi

Uluslararası Yerel Yönetimler Birliği, Doğu Akdeniz ve Orta Doğu Bölge Teşkilatı; Türkiye Belediyeler Birliği, Denizli Merkez, İstanbul Büyükçekmece Belediyesi

Unesco Yaratıcı Şehirler Ağı; Kütahya Merkez Belediyesi

Uyuşturucuya Karşı Mücadele Veren Avrupa Kentleri; İstanbul Büyükşehir Belediyesi

Yaratıcı Şehirler Ağı Gaziantep Büyükşehir; İstanbul Büyükşehir Belediyesi

Yaşlı Dostu Kentler; Mersin Büyükşehir Belediyesi

Yerel Demokrasi Ajansları Birliği; Türkiye Belediyeler Birliği, Marmara Belediyeler Birliği

Sanatlar Organizasyon Konseyi; Gaziantep Büyükşehir Belediyesi

Uluslararası Fotogrametri ve Uzaktan Algılama Uzay Bilimi; İstanbul Büyükşehir Belediyesi

Uluslararası Göç ve Kalkınma Merkezi; Türkiye Belediyeler Birliği

Uluslararası Herkes İçin Spor Derneği; İzmir Karşıyaka Belediyesi

Uluslararası Kağıt Yapımcıları ve Sanatçıları Derneği; Yalova Belediyesi

Kaynak: Çevre ve Şehircilik Bakanlığı Yerel Yönetimler Genel Müdürlüğü, https://yerelyonetimler.csb.gov.tr/ Erişim: 07.05.2021.

\section{YEREL YÖNETIM DİPLOMASISİ UYGULAMALARININ TÜRKIYYE'DEKİ HUKUKSAL ALTYAPISI}

Türkiye'de bulunan birçok büyükşehir belediyesi, ilçe belediyesi ve belediye birliği yerel yönetim diplomasisi faaliyetlerine destek olmakta ayrıca kendileri de birçok proje gerçekleştirmektedir. Yerel yönetimlerin yurtdışındaki muadilleri ile yapacakları yerel diplomasiye dair faaliyetleri ile ilgili olarak izlemeleri gereken hukuki bir süreç de mevcuttur. Bu sürecin başlangıç noktasını 5393 sayılı Belediye Kanunu'nun 74. maddesi oluşturmaktadır. Bu kanun maddesine göre; Belediyeler, belediye meclisinin kararına bağlı olarak görev alanıyla ilgili konularda faaliyet gösteren uluslararası teşekkül ve organizasyonlara, kurucu üye veya üye olabilmektedir. Belediyelerin teşekkül, organizasyon ve yabancı mahallî idarelerle ortak faaliyet ve hizmet projeleri gerçekleştirmesi veya kardeş kent ilişkisi kurabilmeleri de kanunda yer bulmuştur. Ayrıca, birinci ve ikinci fikra gereğince yapılacak faaliyetlerin, diş politikaya ve uluslararası anlaşmalara uygun olarak yürütülmesi ve önceden Çevre ve Şehircilik Bakanlığının izninin alınması zorunluluğu olduğu ifade edilmektedir (Mevzuat, 2005, s. 36). 
Yine 5393 sayılı Kanunun 18. maddesi içerisinde bulunan (p) bendinde belediyelerin yurt içindeki ve yurt dışındaki belediyeler ve mahallî idare birlikleriyle (Çevre ve Şehircilik Bakanlığının izniyle) iş birliği tesis edilmesinde Belediye Meclisinin yetkilendirmesiyle; kardeş şehir ilişkisi kurulması; ekonomik ve sosyal ilişsiler tesisi etmek maksadıyla kültür, sanat ve spor alanlarında faaliyet ve projeler gerçekleştirilmesi; amaciyla arsa, bina ve benzeri tesisleri yapma, yaptırma, kiralama veya tahsisine karar verme konusu ele alınmaktadir (Mevzuat, 2005, s. 11).

5393 sayılı Kanuna ek olarak 1173 sayılı "Milletlerarası Münasebetlerin Yürütülmesi ve Koordinasyonu Hakkında Kanunun" 1. maddesi de yerel yönetim diplomasisine atıf yapan bir içeriğe sahiptir. Bu maddenin 6 . fikrası içerisinde mahalli idareler de zikredilmekle beraber; genel ve katma bütçeli bakanlık, daire ve kuruluşları, kamu iktisadi teşebbüsleri, özel kanunla kurulmuş olan bankalar, kamu kurumu niteliğindeki meslek kuruluşları ve kamu yararına çalışan derneklerden özel gelir kaynakları ve özel imkânları kanunla sağlanmış olanlar, yabancı devlet büyükelçilik, elçilik, başkonsolosluk, konsolosluk, fahri başkonsolosluk ve fahri konsoloslukları ve sair misyonları ve milletlerarası kurullar temsilcilikleri, misyonları ve bunlara bağlı müşavirlik, ataşelik, büro ve sair mercilerle temasları, milletlerarası hukuk kurallarına ve usullerine uygun olarak yapılacağı ifadesi bulunmaktadır. Bu temaslardan Dışişleri Bakanlığına bilgi verileceği belirtilmektedir (Mevzuat, 1969, s. 3).

Türkiye Cumhuriyeti İçişleri Bakanlığı tarafından yayınlanan 07.04.2005 tarihli ve 2005/36 sayılı Genelge 20.06.2005 tarihli ve 2005/62 sayılı Genelgeler de yerel yönetimlerin dış ilişkilerini ilgilendiren maddeler içermektedir. Buna göre 07.04.2005 tarihli ve 2005/36 sayılı Genelgede kullanılan ifadeye göre (Mevzuat, 2005, s. 10-11); Belediyelerin, belediye meclisinin kararına bağlı olarak görev alanıyla ilgili konularda faaliyet gösteren uluslararası teşekkül ve organizasyonlara kurucu üye veya üye olmada veya yabancı mahallî idarelerle ortak faaliyet ve hizmet projeleri gerçekleştirmede veya kardeş kent ilişkisi kurmada Bakanlıktan önceden izinli olmalarının önemi vurgulanmaktadır. Buna göre müracaat edilmesi gereken bilgi ve belgeler şu şekilde bildirilmektedir:

a) Yurt dışındaki bir belediye ile kardeş kent ilişkisi kurulmasında ilgili belediye meclisinin kararı, kardeş kent ilişkisi kurulacak olan kent hakkında bilgi ve kardeş kent ilişkisinden beklenen faydaların neler olduğu, kardeş kent ilişkisi kurulurken kardeş kent protokolleri de imzalanacaksa ilgili protokollerin metni.

b) Uluslararası kuruluşlara üye olunacaksa, ilgili belediyenin meclis kararı, üye olunacak uluslararası kuruluşun ana statüsünün tam metni ile tasdikli Türkçe çevirisi, üyelikten beklenen faydalar, üyelikte bir katılım payı veya aidat ödenecek ise miktarı ile belediyenin en son kesin hesap özeti.

c) Uluslararası kuruluşlarla birlikte eğitim ve kültür faaliyetleri yürütülmesi ve festivaller düzenlenmesi halinde, uluslararası kuruluş hakkında bilgi ve ilgili belediyenin meclis kararı bulunmalıdır. Bunun yanı sıra belediye başkanları ve belediyeyi temsil eden heyetler, yurt dışındaki faaliyetlerinin devletin dış politikasına ve uluslararası anlaşmalara uygun olarak yürütmeleri gerektiği bildirilmektedir. Ayrıca yurtdışına çıkış amacı, süresi ve program hakkında Bakanlığa iletilmek üzere önceden ilgili valiliğe bilgi verilmesi gerektiği de belirtilmektedir. Yurt içindeki belediyeler arasında kardeş kent ilişkisinin ise ilgili belediyelerin karşılıklı meclis kararları ile kurulabileceği belirtilmektedir. 
20.06.2005 tarihli ve 2005/62 sayılı Genelgede kullanılan ifadeye göre ${ }^{4}$; Mahalli idarelerin yurtdışı ilişkileri ile ilgili olarak uygulamada karşılaşılan bazı farklılıkların ve tereddütlerin giderilmesi, yurtdışı ilişkilerde göz önüne alınması gereken hususlar ve istenilen belgeler hakkında bilgilendirilmesi amacıyla "Yurt dışı ilişkiler" başlıklı olarak yayınlanmış olduğu beyan edilerek; Belediyelerin seçilmiş ve atanmış personelinin yurtdışı görevlendirmelerinde uyulacak esasların ilgili genelgelerle belirlendiği ifade edilmektedir. Buna istinaden, yurtdışı görevlendirmelerde bazı esaslara dikkate edilmesi gerektiği belirtilmektedir. Buna göre:

a) Belediyelerin bütçelerinden kendi görev ve hizmet konuları dışında harcama yapılamayacağından, görev ve hizmetle ilişkisi olmayan konular için yurtdışı görevlendirme yapılmayacaktır.

b) Görevlendirmeler; azami tasarruf ilkelerine uygun olarak, asgari sayıda personel ve asgari süreler için yapılacaktır.

c) Görevlendirmeler için belediye meclisinden karar alınacaktır.

d) Toplantı, kongre, seminer, panel vb. organizasyonlara katılmak için görevlendirilen personelde katılım için gerekli olan, yabancı dil bilgisi ve nitelikler aranacaktır.

e) Kamu kurum ve kuruluşları, Belediye birlikleri ve "kamuya yararlı dernek" statüsünde bulunan mahalli idare dernekleri dişındaki kişi, dernek, şirket, vakıf vb. kuruluşlar tarafindan kurs, seminer, inceleme gezisi vb. adlarla yurtdışında düzenlenen programlar için personel görevlendirilmeyecek, harcırah ödenmeyecektir.

f) Toplant1, kongre, seminer, panel vb. organizasyonlar ile kardeş şehir ilişsileri nedeniyle görevlendirmelerde, organizasyonu düzenleyen kuruluş (Belediye, belediye birliği veya uluslararası kuruluş vb.) veya resmi makamlar tarafından yapılmış davet yazıları aranacaktır.

g) Yurtdışı görevlendirmeler ve temaslar hakkında belediye meclisine ilk toplantıda bilgi verilecektir.

h) Görevlendirilen personele 6245 sayılı Harcırah Kanunu hükümlerine göre harcırah (yol+yevmiye) giderleri dışında herhangi bir ödeme yapılmayacaktır.

i) Organizasyonu düzenleyen kuruluşa (var ise) herhangi bir ad altında (eğitim gideri, hizmet satın alınması, konaklama ücreti, rehberlik ücreti vb.) ödeme yapılması mümkün değildir.

j) Görevlendirilen personelle birlikte yurtdışına çıkan eş ve çocuklar için Belediye bütçesinden herhangi bir ödeme yapılması mümkün değildir.

k) Belediye bütçesinden ödeme gerektiren veya gerektirmeyen her türlü yurtdışı görevlendirmelerde yukarıda sayılan usul ve esaslara uyulacak ve yurtdışına çıkışın amacı, süresi ve program hakkında Bakanlığımıza iletilmek üzere önceden ilgili valiliğe bilgi verilecektir.

1) Belediye başkanı ve diğer personelin görev dışında yurt dışına çıkışlarında da ilgili valiliğe bilgi verilecektir.

\footnotetext{
${ }^{4}$ Söz konusu genelge; İçişleri Bakanlığı’nın 20.06.2005 tarih ve (2005/62) 5003-50520 sayıll "Yurt Dışı Görevlendirme" konulu genelgesidir.
} 
Yukarıdaki maddelerin yanı sıra; belediye başkanlarının ve belediyeyi temsilen giden heyetlerin yurt dışındaki faaliyetlerinin devletin diş politikasına ve uluslararası antlaşmalara uygun olarak yürütülmesi gerektiği ve yurtdışına giden belediye görevlilerinin İçişleri Bakanlığınca Dışişleri Bakanlığına bildirileceği belirtilmektedir. Bunun yanında görevli olarak gidilen ülkeden ziyarette bulunacak olan heyetin tutumu ile ilgili olan ifadede ise "Dış temsilciliklerimizden, önceden mutabakata varılanlar haricinde, resepsiyon, tercüman ve mihmandar tahsisi, randevu temini gibi dış temsilciliklerimizin imkanlarını aşabilecek taleplerde bulunulmayacak; özel nitelikteki ziyaretlere dış temsilciliklerimizin ismini kullanarak resmi hüviyet kazandırılmaya çalışılmayacaktır. Ayrıca, yurtdışında bulunulduğu sürece olumsuz imaj ve değerlendirmeye yol açabilecek tutum ve davranışlara meydan verilmeyecektir" denilmektedir. Bunun yanında "Bu konuda Bakanlığımızca yayınlanan ilgi genelgelerin bu genelgeye aykırı hükümleri geçersizdir" ifadesi de genelgede yer almaktadır.

Belediyelerin yurt dişı ilişkilerinin davet, ziyaret, fuar, festival, kültür ve sanat etkinlikleri, kurtuluş yıldönümü, uluslararası önemli günler, toplantı, konferans gibi bazılarının süre ile sınırlı olması gerektiği belirtilerek Bakanlıkça verilecek izinlerin, görüşlerin, etkinliklerin yapılacağı tarihten önce çıkarılabilmesi için yurtdışı ilişkilerle ilgili mevzuat gereği istenilen bilgi ve belgelerin yetkili makamlara zamanında ve eksiksiz olarak ulaştırılması ile mümkün olduğu vurgulanmaktadır. Ayrıca, belediyelerin yurt dışı ilişkilerinin sağlıklı oluşturulabilmesi ve yürütülebilmesi için özellikle İçişleri Bakanlığınca bu konuda yayınlanmış ve Maliye Bakanlığınca verilmiş bulunan yukarıda zikredilen genelge ve görüşlerdeki usul ve esaslara göre konu ile ilgili dosyalarını hazırlamalarının öneminde de değinilmektedir.

\section{KARDEȘ ȘEHIR UYGULAMASI VE ISTANBUL ÖRNEĞi}

Yerel dış politikanın gelişmesi bunun yanı sıra hem küresel hem de yerel ortaklıkların kurularak sürekli büyümesi neticesinde sınır ötesi işbirlikleri yerel yönetim diplomasisiyle iç içe geçmiştir. Öyle ki kardeş şehir ilişkileri, yerel yönetim birlikleri gibi birçok unsur yerel yönetim diplomasisini belirleyen ve etkinliği gösteren başat figürler olarak önem kazanmıştır. Türkiye'de hem büyükşehir belediyesi hem de ilçe belediyeleri düzeyinde birçok kardeş şehir ilişkisi kurulmakta olup bu ilişkilerin sayısı ve etkileşimi bakımından İstanbul şehri ön planda görülmektedir.

\subsection{Kardeş Şehir Uygulaması}

Yerel yönetimlerin kamu diplomasisi adına katkı sunduğu yerel yönetim diplomasisinin en önemli uygulamalarının başında kardeş belediye ya da kardeş şehir uygulamaları gelmektedir. Bu kapsamda Türkiye'deki birçok belediye yurt dışındaki yerel yönetimler ve uluslararası kuruluşlarla işbirliği ve ortaklık anlayış1 geliştirmektedir (MBB, 2018). Kardeş şehirler her şeyden önce; iki kent, ülke, il, vilayet, bölge ve hatta coğrafi ve politik olarak uzak bölgelerde bulunan ülkeler arasında kültürel ve ticari bağların teşvik edilmesini amaçlayan yasal ve sosyal anlaşmalardır. En eski kardeş şehir ilişkisinin 836 yılında Fransa'daki Le Mains ve Almanya'daki Paderborn arasında kurulan ortak kültürel iş birliği çerçevesinde geliştiği (Ogawa, 2012, s. 11) ifade edilse de günümüzdeki anlamda kardeş şehir ilişkisinin ilk kez 1920 yılında Birleşik Krallık'taki Keighley ve Fransa' daki Poix-du Nord arasında gündeme geldiğini belirtmek gerekmektedir (Baş, 2017: 31).

Bununla birlikte şehir eşleştirme konsepti, 1947 yılında İkinci Dünya Savaşı sonrasında düşünülmüş olup bir barış ve uzlaşma eylemi olarak farklı kültürler ve eski düşmanların arasındaki anlayış ve dostluğun geliştirilmesi ile turizm ve ticaretin teşvikini hedeflemiş̦tir. Bu noktada İkinci Dünya Savaşı'ndan sonra savaşta 
zarar gören şehirler için “Tek Dünya Programı”nın kurulmasıyla gelişecek olan kardeş şehir ilişkilerinin olumlu etki yapacağı düşünülmekteydi ancak henüz tam olarak teşekkül etmiş bir kurumsal yapının bulunmayışı Başkan D. Eisenhower'1 1956'da uluslararası ilişkileri için "People to People International” derneğini kurmaya teşvik etmiştir. Bu dernek cemiyeti oluşturan farklı bireylerin ve aktif toplulukların "vatandaş diplomasisinde" yer almasını sağlamak amacıyla ortaya çıkmıştır. (Cremer 1998: 449'den akt. O’Toole, 2001: 403). Sister Cities International (SCI), 145 ülkede 2.100 toplulukta ilişkileri bulunan, Amerika Birleşik Devletleri'nde 545 'ten fazla bireysel kardeş şehir, ilçe ve eyalette ulusal üyelik organizasyonu olarak hizmet vermektedir. Kardeş şehir ağı, sanat ve kültür, gençlik ve eğitim, ekonomik ve sürdürülebilir kalkınma ve insani yardıma odaklanan programlar ve projeler aracılığıyla barışı ve anlayışı geliştirmek için yorulmadan çalışmakta on binlerce vatandaş diplomat ve gönüllüyü bir araya getirmektedir (Sister Cities International, 2014-2015, s. 2)

Avrupa özelinde ise Fransa ve Almanya'nın öncülük ettiği kardeş şehir sürecinin 1951'de kurulmuş olan Avrupa Belediyeler Konseyi'nin de yaptığı etki ile hızla Batı Avrupa'nın diğer şehirlerini de sürece dahil ettiği görülmektedir. Ayrıca, AB Güney ve Doğu Avrupa ülkelerine doğru sınırlarını genişletirken bu süreçte gelişen kardeş şehir ilişkilerinin demokrasinin gelişimine ve bütünleşme anlamında sürece katkı sağladığ görülmüştür (Clarke, 2011, s. 5). 2000’li yıllara gelindiğinde ise şehir eşleştirme ülkeler arasında uluslararası stratejik iş bağlantıları kurmak için kullanılan bir metot olmuştur (TBB, 2018).

Bir ortaklık modeli olarak önerilen kardeş şehirciliğin amacının bazen ulusal ve uluslararası kentlerin kültürel ilişkilerini tanıtmak, bazen de bölgesel ya da kentsel gelişimini sağlamak olduğu belirtilmekle beraber esasında barışın egemen kılınmasının niha hedef olduğu görülmektedir. Ülkelerin yerel yönetimleri diğer bir ifadeyle belediyeleri bazen gönüllülük bazen de stratejik konumları icabı, ekonomik kaygı gibi nedenler de dâhil olmak üzere, çeşitli ortaklıklar tesis edebilmektedir. Gelinen süreçte yönetişim kavramının ortaya çıkışıyla küresel boyutta şehirlerin ve ülkelerin, 'küresel şehirler diyaloğu' üzerine odaklandığ görülmektedir. $\mathrm{Bu}$ noktada coğrafi anlamda uzak mekanlarda bulunan şehirlerin kardeş şehircilik kavramı etrafında kenetlenerek kültürel, ticari ve sosyal amaçlar bakımından birliktelikler kurudukları bir süreç gelişmiştir. Böylelikle zamanla yaşanan değişim neticesinde teknolojik ve bilimsel imkanlar ve küreselleşmenin etkisiyle ihtiyaçların artışı ve çeşitlenmesi nedeniyle ülkeler arasında temas kurulması süreci bir zorunluluğa evrilmiştir (Zeren, Aktulun, 2018, s.8).

Türkiye'de son yıllarda uygulaması giderek artan kardeş şehir ya da şehir eşleştirme metoduyla Türkiye'deki belediyeler hizmet sunum kalitesini, yönetimlerini ve sosyo-ekonomik kalkınmayı geliştirmek yönünde adımlar atma imkânına sahip olmuşlardır. Ancak kardeş şehir ilişkilerinin kimi zaman "boşa kurulan ilişkiler”, "kaynakların gereksiz yere harcanması” gibi gerekçelerle eleştirildiği de görülmektedir (TBB, 2018).

Türkiye'deki belediyelerin kardeş şehir ilişkilerine dair Çevre ve Şehircilik Bakanlığı tarafindan düzenli olarak veri tutulmakta olup Bakanlığın 9 Haziran 2020'de yayınladığı "Belediyelere Ait Kardeş Kent İstatistikî Verileri” çalışmasına göre Türkiye'deki belediyelerin 1863 adet kardeş şehri bulunmaktadır (ÇŞB, 2020). Ayrıca yine Çevre ve Şehircilik Bakanlığının çalışması olan 9 Haziran 2020'de yayınlanan "Belediyelerin Uluslararası Kuruluş Üyeliklerine İlişkin İstatistikî Veriler” çalışması da yerel yönetim diplomasisi alanında Türk yerel yönetimlerinin güncel durumunu ortaya koymaktadır (ÇŞB, 2020).

Türkiye'de son yıllarda kardeş şehir uygulamalarının geliştirilmesi, sürdürülebilir ve işlevsel olabilmesi adına birçok çalışma gerçekleştirilmekte olup bu noktada; Türkiye Belediyeler Birliğinin (TBB) bir girişimi olan 
"Kardeş Şehir Arıyorum"5 girişimini de anmak yerinde olacaktır. Bu çalışma, kardeş şehir ilişkisi kurmak düşüncesinde olan belediyelerin işbirliği geliştirmeyi hedefledikleri alanların tam olarak sağlanması maksadıyla kurulan bir belediye ve ilgili alanı eşleştirme çalışması özelliğini taşımaktadır. Bu çalışma içerisinde bulunan sorular şehirler arasında eşleştirmenin yapılmasına önemli ölçüde katkı sağlamaktadır. Buna göre kardeş şehir ilişkisi kurmak isteyen belediyelerin bilgilerinin sonrasında; a. Kardeş Şehir/Şehir Eşleştirme İşbirliği Temaları, b. Tarihi/Doğal/Coğrafi Özellikler, c. Sosyo-ekonomik Özellikler gibi başlıklar bulunmaktadır. Bu başlıklar arasından sırasıyla;

a. Kardeş Şehir/Şehir Eşleştirme işbirliği temaları başlığı altında yerel yönetimlerin ilgi alanına göre tasnif edilmesi aşağıdaki sorularla hedeflenmektedir;

$\checkmark$ Tarım ve kırsal kalkınma,

$\checkmark$ Kültür turizm ve marka şehirler,

$\checkmark$ Farklılık bütünleşme sığınmacılara ev sahipliği,

$\checkmark$ Ekonomik ve sosyal uyum,

$\checkmark$ Çevre ve iklim değişikliği,

$\checkmark$ Cinsler eşitliği,

$\checkmark$ Sağlık ve ferah,

$\checkmark$ Yönetişim demokrasi ve yurttaşlık,

$\checkmark$ Konut ve insan yerleşimleri,

$\checkmark$ Uluslararası bağlantı işbirliği ve proje yönetimi,

$\checkmark$ Yerel ve bölgesel kamu hizmetleri yönetimi,

$\checkmark$ Akıllı şehirler ve kentsel ulaşım,

$\checkmark$ Atık yönetimi, temiz su ve sanitasyon,

$\checkmark$ Gençlik ve spor gibi sorulardır (TBB, 2018).

b. Tarihi/Doğal/Coğrafi Özellikler temaları başlığı altında yerel yönetimlerin coğrafi özelliklerine göre tasnif edilmesi aşağıdaki sorularla hedeflenmektedir;

$\checkmark$ Başkent,

$\checkmark$ Dünya mirası listesindeki veya özel statüdeki koruma alanı,

$\checkmark$ Tarihi-kültürel nirengi noktası (Kale, şehir duvarları, anıt yapı vd.),

$\checkmark$ Kıy1(Deniz),

$\checkmark$ Kiyı (Göl),

$\checkmark$ Nehir havzas1,

$\checkmark$ Dağlik,

5 Türkiye Belediyeler Birliği (TBB) yerel diplomasi web sayfası, detaylı bilgi için bkz. http://www.yereldiplomasi.gov.tr/kardes-ariyorum-tr/. 
$\checkmark$ Tarım arazisi,

$\checkmark$ Ormanlık ve koruluk,

$\checkmark$ Sulak alandir (TBB, 2018).

c. Sosyo-ekonomik Özellikler başlığı altında yerel yönetimlerin sosyo-ekonomik özelliklerine göre tasnif edilmesi aşağıdaki sorularla hedeflenmektedir;

$\checkmark$ Bulunduğu bölgenin ekonomik, ticari merkezi,

$\checkmark$ Turizm cazibe merkezi (Yaz),

$\checkmark$ Turizm cazibe merkezi (Kış),

$\checkmark$ Eko-turizm,

$\checkmark$ Liman ve marina tesisleri,

$\checkmark$ Balıkçılık ve su ürünleri,

$\checkmark$ Ağırlıklı olarak tarıma dayalı yerel ekonomi gibi sorulardır (TBB, 2018).

$\mathrm{Bu}$ veriler ışığında Türkiye Belediyeler Birliği tarafından yürütülen kardeş şehir ilişkisi yapılması yolunda atılan adımlarda sürdürülebilir bir yol izlendiği görülmektedir. Bu çalışmalardaki verimliliğin artmasında belediyelerin geliştirdiği işbirliklerinin yanında yurt dışında faaliyetleri bulunan ulusal kurum ve kuruluşların (Dışişleri Bakanlığı, Türk İşbirliği ve Koordinasyon Ajansı, Türkiye Maarif Vakfı, Yunus Emre Enstitüsü vb.) çalışmalarının da dikkate alınmasının gerekli olduğu görülmektedir. Türkiye'deki yerel yönetimlerin birlikte hareket etmesi için uygun ortamın hazırlanmasında önemli rolü olan Türkiye Belediyeler Birliği yapılacak olan yerel diplomasi çalışmalarının koordinasyonuna önemli katkılar sunmaktadır (TBB, 2019, s. VII).

Türkiye Cumhuriyeti Dışişleri Bakanlığı'na bağlı Avrupa Birliği Başkanlığının ana yararlanıcı olduğu "Şehir Eşleştirme Projesi" de yerel yönetim diplomasisi ve kardeş şehir uygulaması için oldukça önemli olup, ele alınması gerekmektedir. Bu projede İçişleri Bakanlığı, Çevre ve Şehircilik Bakanlığı Yerel Yönetimler Genel Müdürlüğü, Türkiye Belediyeler Birliği (TBB) ve Vilayetler Birliği projenin temel paydaşları sıfatıyla çalışmada yer almaktadırlar (TBB, 2019, s. 1). Projenin uygulama dönemi 6 Nisan 2018 ile 5 Nisan 2020 tarihleri arasını kapsayan 24 ay süreli bir periyotta gerçekleştirilmiştir (TBB, 2019, s. 3). Proje çerçevesinde Merkezî Finans ve İhale Birimi (MFIB) ise projenin sözleşme makamı olarak katkı sunmuştur. Şehir eşleştirme çalışmasını emsallerinden farklı kılan özelliğin ise diğer çalışmalara nazaran daha uzun döneme yönelik olduğu belirtilmektedir. Proje bu açından sahip olduğu üst düzey hedefler sayesinde tanımlanırken; "ortak değerler ve ilkeler bütünü çerçevesinde farklı toplumları bir araya getirip yakınlaştıran, sorunlara el birliğiyle çözümler getirilmesine olanak veren, deneyim paylaşımı sayesinde kaynakların daha etkin ve verimli kullanılmasını sağlayan ve böylece hizmet niteliğini arttırarak vatandaş memnuniyetinin ve yaşam standardının yükselmesine ve sosyo-ekonomik kalkınmaya katkı yapan demokratik ve katılımeı bir yaklaşımdır" biçiminde ifade edilmektedir (TBB, 2019, s. 5-6).

Yürütülmekte olan bu projenin şehirleri ilgilendiren odak noktaları bulunmaktadır. Bunlar;

$\checkmark$ Yerelleşme (yerindenlik, yetki devri vb.),

$\checkmark$ Kültürler arası paylaşım (dil, tarih, sanat, gençlik, spor vb.), 
$\checkmark$ Teknik deneyim paylaşımı (kamu hizmetlerinde etkinlik ve verimlilik, mali yönetim, liderlik, insan kaynakları vb.),

$\checkmark$ İyi yönetişim (katılım, saydamlık, hesap verebilirlik, hukukun üstünlüğü vb.),

$\checkmark$ Politika geliştirme (planlama, analiz, izleme, değerlendirme vb.),

$\checkmark$ Yerel ekonomik kalkınma (tarım, turizm, ticaret, ulaşım, altyapı vb. sektörler), sosyal kalkınma (eğitim, istihdam, sağlık, toplumsal cinsiyet eşitliği, sosyal hizmetler, sosyal uyum ve içerme vb.),

$\checkmark$ Çevre koruma (enerji, iklim, sürdürülebilirlik, doğal kaynaklar vb.),

$\checkmark$ Kriz yönetimi (afet, acil durum, kitlesel göç vb.),

$\checkmark$ Teknoloji aktarımı (yenilik, bilişim ve yönetim teknolojileri vb.),

$\checkmark$ Araştırma ve geliştirme (bilimsel işbirliği, yönetim ve hizmet laboratuarları vb. biçiminde siralanmaktadir (TBB, 2019, s. 7).

Kardeş şehir ilişkisi kurulmasından daha uzun dönemli bir biçimde olması tasarlanan "Şehir Eşleştirme" çalışmalarının tamamlayıcı faaliyetler dizisi yürüttüğü görülmektedir. Buna göre bu faaliyetlerin sırasıyla; düzenli etkinlikler (festival, konferans, seminer, eğitim vb.), çalışma ziyareti, kapasite geliştirme faaliyetleri, proje uygulama, personel değişimi, düzenli bilgi ve deneyim paylaşımı için iletişim ağları kurulması, analiz, izleme ve değerlendirme çalışmaları, yenilikçi bilgi sistemleri paylaşımı, ortak yöntem, rehber ve araçlar geliştirilmesi, yasal düzenlemelerin iyileştirilmesi, uluslararası standartlar geliştirilmesi biçiminde geliştiği gözlenmektedir (TBB, 2019, s. 8)

TBB'nin de kendi kurumsal çalışması olarak yer aldığı "Şehir Eşleştirme” çalışmalarına dair örnek sunmak gerekirse: Türk-İsveç Yerel Yönetimler Ortaklı̆̆ı; Belediye Ortaklık Ağları Projeleri, Türkiye ve İspanya Belediyeleri Arasında İşbirliğinin Geliştirilmesi Projesi, Türkiye ile Hollanda Belediyeleri Arasında Kurulan Ortaklıklar, Yerel Yönetim Reformunun Devamına Destek Projesi (LAR II), Valiliklerde AB İşleri için Kapasite Oluşturulması için Teknik Destek Projesi (VABpro) gibi çalışmalar önemli örnekler olarak sunulabilir (TBB, 2019, s. 20-27).

\subsection{Kardeş Belediye Uygulaması: İstanbul Örneği}

Türkiye'de merkezi idareye bağlı kurum ve kuruluşların dışında kamu diplomasisi faaliyetlerinde yerel yönetimlerin de diplomaside önemli bir etkinliği bulunmaktadır. Türkiye'de bulunan birçok büyükşehir belediyesi ile ilçe belediyesi hem merkezi idarenin kamu diplomasisi faaliyetlerine destek olmakta hem de kendileri de birçok girişim ve faaliyetler gerçekleştirmektedir. Büyükşehir belediyeleri ile ilçe belediyelerinin başta Dış İlişkiler Müdürlüklerinin koordinasyonunda yurt dışında gerçekleştirdikleri projeler özellikle teknik destekler ve hibeler ile insani yardımlar Türk kamu diplomasisi adına önemli katkılar sağlamaktadır. Bu anlamda İstanbul Büyükşehir Belediyesi, Bursa Büyükşehir Belediyesi, Kocaeli Büyükşehir Belediyesi, Bayrampaşa, Fatih, Gaziosmanpaşa ve Sultangazi Belediyeleri gibi belediyeler öne çıkan yerel yönetim birimleridir. Ancak bunlar arasında Türkiye'de yerel yönetim diplomasisinde en önemli aktörlerin başında İstanbul Büyükşehir Belediyesi (IBB) ve İstanbul ilçe belediyeleri gelmektedir (Eren, 2018, s. 88).

Türkiye Belediyeler Birliği tarafından sağlanan bilgilere göre; kardeş şehir işbirliklerinin büyük çoğunluğunun Türkiye'deki 30 büyükşehir belediyesi ve bu belediyelerin ilçelerinde yoğunlaştığı görülmektedir. Bu bilgilere 
göre; İstanbul'un tüm belediyeleri 281 işbirliğiyle önde gelmektedir (TBB, 2018). İstanbul Büyükşehir Belediyesi'nin kardeş şehir ilişkisi incelendiğinde ise; İBB'nin 55 Kardeş Şehir, 20 İşbirliği Protokolü6 ve 29 Mutabakat Zapt1/İyi Niyet Protokolü7 bulunduğu görülmektedir. (İBB, 2020).

Tablo 2: İstanbul Büyükşehir Belediyesi Kardeş Şehirleri

\begin{tabular}{|c|l|l|l|l|l|}
\hline 1 & İsfahan & İran & 29 & Guangzhou & Çin Halk Cum. \\
\hline 2 & Venedik & İtalya & 30 & Ho Chi Minh & Vietnam \\
\hline 3 & Nursultan & Kazakistan & 31 & Kazablanka & Fas Krallı̆̆ \\
\hline 4 & Amman & Ürdün & 32 & Kazan & Tataristan \\
\hline 5 & Amsterdam & Hollanda & 33 & Kong & Fildişi Sahili \\
\hline 6 & Atina & Yunanistan & 34 & Köln & Almanya \\
\hline 7 & Bağdat & Irak & 35 & Köstence & Romanya \\
\hline 8 & Bangkok & Tayland & 36 & Kyoto & Japonya \\
\hline 9 & Barselona & İspanya & 37 & Lefkoşa & K.K.T.C \\
\hline 10 & Belgrad & Sirbistan & 38 & Lizbon & Portekiz \\
\hline 11 & Beyrut & Lübnan & 39 & Meksiko City & Meksika \\
\hline 12 & Bingazi & Libya & 40 & Merv & Türkmenistan \\
\hline 13 & Brüksel & Belçika & 41 & Mery & Türkmenistan \\
\hline 14 & Budapeşte & Macaristan & 42 & Mogadişu & Somali \\
\hline 15 & Buenos Aires & Arjantin & 43 & Napoli & İtalya \\
\hline 16 & Bükreş & Romanya & 44 & Odessa & Ukrayna \\
\hline
\end{tabular}

${ }^{6}$ İBB'nin işbirliği protokolü imzaladığı belediyeler; Floransa (İtalya), Toronto (Kanada), Stockholm (İsveç), Strazburg (Fransa), Varşova (Polonya), Budapeşte (Macaristan), Prag (Çekya), Havana (Küba), Kabil (Afganistan), Xi'an (Çin), Atina (Yunanistan), Napoli (İtalya), Seul (Güney Kore), Bükreș (Romanya), Moskova (Rusya), Paris (Fransa), Kazablanka (Fas), Viyana (Avusturya), Lahor (Pakistan) ve Kyoto (Japonya)'dir.

7 İstanbul Büyükşsehir Belediyesinin Mutabakat Zapt//İyi Niyet Protokolleri bulunan şehirleri ise şu şekilde sıralanmaktadır; Paris (Fransa), Milano (İtalya), Berlin (Almanya), Tiflis (Gürcistan), Pecs (Macaristan), Isfahan (İran), Tebriz (İran), Gyeongsangbuk-do (Güney Kore), Pencap (Pakistan), Rabat (Fas), Bogota (Kolombiya), Karaçi (Pakistan), Frankfurt/Main (Almanya), Aden (Yemen), Mekke (Suudi Arabistan), Juba (Güney Sudan), Dakar (Senegal), Monrovia (Liberya), Akra (Gana), Encemine (Çad), Guangzhou (Çin), Mogadişu (Somali), Ulan Bator (Moğolistan), Hangzhou (Çin), Konakri (Gine), Trablus (Libya), Yakutsk (Rusya/Yakutistan), Cakarta (Endonezya) ve Brüksel (Belçika)'dır. 


\begin{tabular}{|l|l|l|l|l|l|}
\cline { 4 - 5 } 17 & Cakarta & Endonezya & 45 & Oş & Kirgızistan \\
\hline 18 & Chittagong & Bangladeş & 46 & Pusan & Güney Kore \\
\hline 19 & Chongqing & Çin Halk Cum. & 47 & Rio De Janeiro & Brezilya \\
\hline 20 & Constantine & Cezayir & 48 & Saraybosna & Bosna-Hersek \\
\hline 21 & Duabi & BAE & 49 & Semerkant & Özbekistan \\
\hline 22 & Durres Suwan & Arnavutluk & 50 & St. Petersburg & Rusya Fed. \\
\hline 23 & Encemine & Çad Cum. & 51 & Şam & Suriye \\
\hline 24 & Filibe & Bulgaristan & 52 & Tebriz & İran \\
\hline 25 & Plovdiv & Bulgaristan & 53 & Tiflis & Gürcistan \\
\hline 26 & Gize & Misir & 54 & Tunus & Tunus \\
\hline 27 & Gomel & Belarus Cum. & 55 & Üsküp & Makedonya \\
\hline
\end{tabular}

Kaynak: Çevre ve Şehircilik Bakanlı̆̆ı Yerel Yönetimler Genel Müdürlüğü, https://yerelyonetimler.csb.gov.tr/ Erişim: 07.05.2021.

İstanbul Büyükşehir Belediyesinin sadece kardeş şehir sayısı 55 iken, Ankara'nın 51'dir. İBB'nin tabloda gösterildiği üzere; Almanya, Arnavutluk, Birleşik Arap Emirlikleri (BAE), Bangladeş, Belarus Cum., Belçika, Bosna-Hersek, Brezilya, Cezayir, Çad Cum., Endonezya, Fas Krallı̆̆ı, Fildişi Sahili, Güney Kore, Gürcistan, Hollanda, Irak, İspanya, Japonya, K.K.T.C, Kazakistan, Kırgizistan, Libya, Lübnan, Macaristan, Makedonya, Meksika, Misır, Özbekistan, Portekiz, Rusya, Sirbistan, Somali, Suriye, Tataristan, Tayland, Tunus, Ukrayna, Ürdün, Vietnam ve Yunanistan'dan birer adet kardeş şehri bulunmaktadır. Bunun yanında İBB'nin aynı tabloda Arjantin, Bulgaristan, Çin Halk Cum., İran, İtalya, Romanya, Türkmenistan ve Yunanistan'dan ikişer adet kardeş şehri bulunmakta olduğu görülmektedir.

İstanbul Büyükşehir Belediyesinin toplamda 90 şehir ile işbirliği mevcutken, Ankara'nın ise 58 yabancı şehir/belediye ile kardeş şehir ilişkisi ile işbirlikleri mevcuttur. İlçe belediyelerine bakıldığında İstanbul ilçe belediyelerinin toplamda 265 kardeş şehri bulunmaktadır (ÇŞB, 2021). Bunun yanında Ankara'nın ise sadece 127'dir (Ankara, 2021).

Tablo 3: İstanbul İlçe Belediyelerinin Kardeş Şehirleri

Adalar; Atina-Paleo Faliro Yunanistan, Çolpan-Ata Kırgızistan, Filibe Bulgaristan, Nacka İsveç, Pokhara Nepal Cumhuriyeti, Veles Makedonya

Arnavutköy; Gazimağusa Beyarmudu K.K.T.C, Studeniçani Makedonya

Ataşehir; Aktöbe Kazakistan, Çek Cumhuriyeti, Lapta K.K.T.C, Monheim Almanya, Provedancia Şili

Avcılar; Komotini(Gümülcine) Yunanistan, Obuda-Bekasmegyer Macaristan, Razgrat Bulgaristan 
Bağcılar; Almatı Kazakistan, Backhoun Lübnan, Buzim Bosna-Hersek, Çimkent Kazakistan, Çorovoda Arnavutluk, Dannieh Lübnan, Deir Al-Balah Filistin, Güzelyurt K.K.T.C, İpek Kosova, Kenitra (Al Kantara) Fas Krallığı, Luplin Polonya, Mehmetçik K.K.T.C, Monrovia Liberya, Pencap Pakistan, Targovishte Bulgaristan, Targovishte Bulgaristan,

Bahçelievler; Bahçesaray Kırım Özerk Cumhuriyeti, Hadzici Bosna-Hersek, Jinja Uganda, Maradi Nijer, Privoljskiy Tataristan, Ujbuda Macaristan, Üsküp Makedonya

Bakırköy; Esentepe K.K.T.C, Minsk Sovetskiy Belarus Cumhuriyeti

Başakşehir; Hartum Sudan Cumhuriyeti

Bayrampaşa; Alsancak K.K.T.C, Batı Şeria Nablus Filistin, Boosaaso Somali, İşkodra Arnavutluk, Jupa Makedonya, Nizami, Azerbaycan, Plasnita, Makedonya, Plav Karadağ, Rozaje Sırbistan-Karadağ, Settimo Torinese İtalya, Şirvan Azerbaycan

Beşiktaş; Bralia Romanya, Bükreş 1.Sektör Romanya, Charlottenburg-Wilmersdorf Almanya, Erlangen Almanya, Herne Almanya, İskeçe (Xanthi) Yunanistan, İskeçe (Xanthi) Yunanistan, Newyork - Brooklyn Amerika Birleşik Devletleri, Obuda Budapeşte, Trecin Slovakya, Tuzla Bosna-Hersek

Beykoz; Duisburg-Dinslaken Almanya, Gardo Somali, İskele K.K.T.C, Mohaç Macaristan, Mülheim An Der Ruhr Almanya, Prizren Kosova, Srebrenitsa Bosna-Hersek, Zakopane Polonya

Beylikdüzü; Girne K.K.T.C, Mangalya Romanya

Beyoğlu; Benilmedana İspanya, Berlin-Mitte (Merkez) İlçe Almanya, Bregenz Avusturya, Bükreş Romanya, Cenova İtalya, Chengdu Çin Halk Cumhuriyeti, Dubrovnik Hırvatistan Filibe Bulgaristan, Hydra Yunanistan İliçevsk Ukrayna, Katanya İtalya, Kore Seoul Seongbuk Güney Kore, Manhattan Amerika Birleşik Devletleri, Peç Macaristan, Tokyo (Bunkyo) Japonya, Üsküp Makedonya, Vitacura Şili

Büyükçekmece; Çayır Makedonya, Çonan Güney Kore, Değirmenlik K.K.T.C, Gorna Oryahovıca Bulgaristan, Güzelyurt K.K.T.C, İskele K.K.T.C, Kranj Slovenya, Nea Propontida Yunanistan, Pavel Banya Bulgaristan, Ramat Gan İsrail, Stockholm İsveç, Struga Makedonya, Voio Yunanistan

Çekmeköy; Berrechid Fas Krallığı, Bilma Nijer, Doyran Makedonya, Güzelyurt K.K.T.C, Vogoş̧̧a Bosna-Hersek

Esenler; Bihaç Bosna-Hersek; Gazze Filistin, Kvaşra Lübnan, Jupa Makedonya, Tahoua Nijer

Esenyurt; İn Gall Nijer, Sarıarka İlçe Başkanlığı Kazakistan

Eyüp; Abalak Nijer, Krasnogvardeyski Rusya, Oleron Fransa, Priyepole Sirbistan-Karadağ, Rochefort Fransa, Üsküp Merkez Makedonya, Gostivar Makedonya, Kram Tunus

Fatih; Akkerman Ukrayna, Gazze Filistin, Hessen-Wiesbaden Almanya, Kalkandelen Makedonya, Sayda Lübnan

Stari Grad Bosna-Hersek

Gaziosmanpaşa; Changzhou Güney Kore, Feodosiya (Kefe) Kırım Özerk Cumhuriyeti, İllela Nijer, Kırcaali Bulgaristan, Ohri Makedonya, Plevne Bulgaristan, Tutin Sirbistan-Karadağ

Güngören; Gorazde Bosna-Hersek, Kayakent Rusya

Kadıköy; Jonava Litvanya, Jupa Makedonya, Kisela Voda Makedonya, Rueil-Malmasion Fransa, Tel Aviv - Petah Tikva İsrail

Kağıthane; Kygnam -Masan Güney Kore

Kartal; Ardıno (Eğridere) Bulgaristan, Banoviç Bosna-Hersek, Buzovna Azerbaycan, Esentepe K.K.T.C, İlfov Romanya, Sitovo Bulgaristan, Sjenica Sirbistan-Karadağ, Varna Asparuhovo Bulgaristan, Visoko Bosna-Hersek

Küçükçekmece; Aalen Almanya, Astana Kazakistan, Gelsenkirchen Almanya, Gümülcine Yunanistan, Hackney İngiltere, Jozsejvaros Macaristan, Mamuşa Kosova, Ostrow Polonya 
Maltepe; Bugojno Bosna-Hersek, Dannieh Lübnan, Değirmenlik K.K.T.C, Komrat Moldova, Loznitsa Sirbistan, Nişabure İran, Tahran 22. Bölge İran, Elbasan Arnavutluk

Pendik; Bakü-Yasamal Rayon Azerbaycan, Budapeşte Macaristan, Cenin Filistin, Cingeltei Moğolistan, Ciampino İtalya, Dipkarpaz K.K.T.C, Gagauz - Komrat Moldova, Isık Göl Olbastı Çolpan Ata Kırgızistan, İskele K.K.T.C, Madan Bulgaristan, Mamuşa Kosova,Nerimanov Azerbaycan, Plasnita Makedonya, Sidi Bernoussi Fas Krallığı, Sigli Kasabası Endonezya, Smolyan Bulgaristan, Targu-Jiu Romanya, Travnik Bosna-Hersek

Sancaktepe; Ciudad Bolivar Kolombiya, Cibuti Cibuti, Gniezno Polonya, Gornji Vakuf Bosna-Hersek, Kenitra Fas Krallığı, Nalayh Moğolistan, Ouagadougou Burkina Faso, Rafah Filistin

Sarıyer; Aachen Almanya, Busan Nam-Gu Güney Kore, Gazimağusa K.K.T.C, Haçmaz Azerbaycan, Jajce BosnaHersek, London Borough Enfield İngiltere, Ravenna İtalya, Vac Macaristan

Silivri; Aydos Bulgaristan, Devnya Bulgaristan, Kırcaali Bulgaristan, Nesvizh Belarus Cumhuriyeti, San Pedro Fildişi Sahili, Starigrad-Sarajevo Bosna-Hersek, Velingrad Bulgaristan, Değirmenköy Devnya Bulgaristan

Sultanbeyli; Jajce Bosna-Hersek

Sultangazi; El-Halil Hahlül Filistin, Filibe Doğu İlçe Bulgaristan, Iferouane Nijer

Şile; Cazin Bosna-Hersek, Idstein Almanya, Idstein Almanya, Paggaio Yunanistan, Queensland-Barcoldıne Avustralya, Tabalak Nijer, Xianyang Çin Halk Cumhuriyeti

Şişli; Auburn Avustralya, Bad Kreuznach Almanya, Belçika, Moskova Merkez İdare Rusya, Seocho-Gu Güney Kore

Tuzla; Bakü - Merdekan Azerbaycan, Drama Yunanistan, Novi Grad Bosna-Hersek, Bosna-Hersek

Ümraniye; Fojnica Bosna-Hersek, Jabalia Nazlah Filistin, Pazarcık Bulgaristan, Stari Grad Bosna-Hersek, Gazimağusa K.K.T.C

Üsküdar; Aksu Azerbaycan, Awcileh Libya, Bahçesaray Ukrayna, Brooklyn Amerika Birleşik Devletleri, İşkodra Arnavutluk, Kaposvar Macaristan, Plasnita Makedonya, Shibuya Japonya, Sidney - Auburn Avustralya, Zenica BosnaHersek, Doha Katar

Zeytinburnu; Beyt Hanoun Filistin, Bissau Gine Bissau Cumhuriyeti, Gala Azerbaycan, Güzelyurt K.K.T.C, Ilidza Bosna-Hersek, İşkodra Arnavutluk, Keita Nijer, Kumanova Makedonya, Nerimanov Azerbaycan, Semipalantinsk Kazakistan, Hırvatistan, Srebrenitza Bosna-Hersek, Stockholm İsveç, Darkhan Moğolistan

Kaynak: Çevre ve Şehircilik Bakanlı̆̆1 Yerel Yönetimler Genel Müdürlüğü, https://yerelyonetimler.csb.gov.tr/ Erişim: 07.05.2021.

Tablo'da gösterilen kardeş şehirlerin bulunduğu ülkelerden; Almanya 14, ABD 3, Arnavutluk 5, Avustralya 1, Avusturya 1, Azerbaycan 11, Belarus 2, Belçika 1, Bosna-Hersek 24, Bulgaristan 22, Burkina Faso 1, Cibuti 1, Çek Cumhuriyeti 1, Çin Halk Cumhuriyeti 2, Endonezya 1, Fas Krallığ 4, Fildişi Sahili 1, Filistin 9, Fransa 3, Gine Bissau Cumhuriyeti 1, Güney Kore 6, Hurvatistan 2, İngiltere 2, İran 2, İspanya 1, İsrail 2, İsveç 4, İtalya 5, Japonya 2, K.K.T.C 19, Karadağ, Katar 1, Kazakistan 6, Kırgızistan 2, Kırım Özerk Cumhuriyeti 2 , Kolombiya 1, Kosova 4, Liberya 1, Libya 1, Litvanya 1, Lübnan 5, Macaristan 9, Makedonya 19, Moğolistan 3, Moldova 2, Nepal 1, Nijer 9, Pakistan 1, Polonya 4, Romanya 6, Rusya 3, Surbistan 1, Karadağ 5, Slovakya 1, Slovenya 1, Somali 2, Sudan 1, Şili 2, Tataristan 1, Tunus 1, Uganda 1, Ukrayna 3, Yunanistan 10 şehirle listede yer almaktadir.

İstanbul Büyükşehir Belediyesi kurmuş olduğu kardeş şehir ilişkileri ve işbirlikleriyle üstlendiği donör sıfatıyla birçok ülkeye çeşitli hibelerde de bulunmaktadır. Bu kapsamda İstanbul Büyükşehir Belediyesi TİKA ile yaptığı ortaklık kapsamında 2016 yılında bir protokol imzalayarak aralarında Gana, Gine, Nijer ve Somali'nin 
de bulunduğu toplamda 9 ülkeye 200 otobüs hibe etmiştir. İBB'nin bu hibe faaliyeti ilk de değildir. İBB 2012 yılında Pakistan'a 100, 2017 yılında Ukrayna'nın Odessa kentine ise 30 otobüs hibe etmiştir (İBB, 2017).

Benzer şekilde hem İBB hem de ilçe belediyeleri yerel yönetim diplomasisinde özellikle Türkiye'ye yakın coğrafyalarda kardeş şehir ilişkileriyle oldukça aktif faaliyetler gerçekleştirmektedir. Bu doğrultuda başta Balkanlar olmak üzere Türk Cumhuriyetleri, Afrika ve Orta Doğu'da gerçekleştirilen toplu sünnet şölenleri, Ramazan ve Kurban programları, sağlık taramaları gibi insani faaliyetler ile kültürel mirasın restorasyonu, belediyecilik hizmetlerinin eğitimi, meslek edindirme kursları gibi teknik çalışmalardır. $\mathrm{Bu}$ tür çalışmalar belediyelerce gerçekleştirildiği gibi Türk Dünyası Belediyeler Birliği gibi çatı kuruluşlarca da yapılabilmektedir (Purtaş, 2013, s. 8).

\section{SONUÇ}

Kökü yüzlerce yıl öncesine dayanan geleneksel diplomasi metodu küreselleşmenin, devletler ve toplumlar arasındaki iletişim ile işbirliği çeşitlerinin değişip gelişmesi neticesinde büyük bir dönüşüme uğramıştır. $\mathrm{Bu}$ dönüşüm neticesinde neredeyse 20. yüzyılın ortalarına kadar devletten devlete süregelen geleneksel diplomasinin yanında devletin dişında birçok yeni aktör öne çıkmaya başlamıştır. Bu aktörleri uluslararası örgütler, çok uluslu şirketler, sivil toplum kuruluşları, medya kuruluşları, baskı grupları, yerel yönetimler vb. olarak sıralamak mümkündür. Bu aktörlerin katılıp etkinlik gösterdiği diplomasi türüne de kamu diplomasisi denmiştir.

Yerel yönetimler de kamu diplomasisinde etkin rol oynayan aktörler olarak dikkat çekmişler, bu noktada başta kardeş şehir ilişkileri, kültürel, insani vb. temalarda gerçekleştirilen faaliyetlerle diplomatik girişimlerde bulunmuşlardır. Yerel yönetimlerin diplomatik girişimleri de literatürde yeni bir terim ile kavramsallaştırılmaya çalışılmıştır. Buna müteakip en sık kullanılan kavramlar ise; Yerel yönetim diplomasisi, yerel diplomasi, şehir/ kent diplomasisi, para diplomasi vb. olmuştur.

Bu çalışmada yerel yönetim diplomasisi kavramı diğer kavramlarla birlikte açıklanmıştır. Bu kavram merkeze alınarak Türkiye'de yerel yönetim diplomasisinin hukuksal alt yapısının oluşup oluşmadı̆̆ı, oluştuysa hangi kanun ve genelgelerle ele alındığına açıklık getirilmiştir. Ayrıca yerel yönetim diplomasisinin en etkili uygulamalarından biri olan kardeş şehir uygulamasının ne olduğu ve bu uygulamaya nasıl başvurulması gerektiğine ilişkin literatürdeki bilgilerden ve bu konuda uzman bir kuruluş olan Türkiye Belediyeler Birliği'nin çalışmalardan atıf yapılmıştır. Son olarak ise kardeş şehir uygulamaları bakımından İstanbul'un hem büyükşehir belediyesi hem de ilçe belediyeleri bakımından büyük oranda öne çıktığına vurgu yapılmıştır. Ayrıca bu belediyelerin hem sayıca kurmuş oldukları ilişki ağları hem de gerçekleştirdikleri yardım/hibe faaliyetleri sayesinde kültürel ve insani çalışmalarla Türkiye'nin yerel yönetim diplomasisinde büyük oranda başat rol oynadıkları sonucuna varılmıştır. 


\section{KAYNAKÇA}

Aktülün, E. ve H. E.Zeren (2018) Yönetişim Çerçevesinde Ortaklıklar ve Belediyelerin Kardeş Şehir İlişkileri: Ankara Büyükşsehir Belediyesi Örneği. ASSAM Uluslararası Hakemli Dergi (ASSAM UHAD) ASSAM International Refereed Journal, Sayı: 11 Y11: 2018.

AFAD. (2014). Türkiye, AFAD Koordinasyonunda Batı Balkanlara Yardım Ediyor. https://www.afad.gov.tr/tr/2946/Turkiye-AFAD-Koordinasyonunda-Bati-Balkanlara-Yardim-Ediyor, Erişim Tarihi: 20.03.2021.

Aguirre, I. (1999). Making Sense of Paradiplomacy? An Intertextual Enquiry About a Concept in Search of a Definition". F. Aldecoa, \& M. Keating içinde, Paradiplomacy in Action, The Foreign Relations of Subnational Governments (s. 185-209). Londra: Frank Cass.

Ankara. (2021). Ankara'nın Kardeş Şehirleri. Ankara Büyükşehir Belediyesi: https://ankara.bel.tr/genelsekreter/genel-sekreter-yardimcisi-faruk-cinki/dis-liskiler-daire-baskanligi/ankaranin-kardessehirleri/, Erişim Tarihi: 03.11.2021.

Baş, C. (2017). Yerel Diplomasi, Türkiye Belediyeler Birliği Dergisi, Sayı: 827-828, Mart -Nisan 2017, ss. $30-50$.

Birgi, M. N., (1983). Diplomasi Mesleği. İstanbul: İstanbul Üniversitesi Siyasal Bilimler Fakültesi Dergisi. Say1: 1.

Berridge, G. R. James, A. (2001). A Dictionary of Diplomacy. New York: Palgrave.

Berridge, G. R., James, A. (2003). A Dictionary of Diplomacy. London: Palgrave Macmillan.

Clarke, N.(2011). Globalising Care? Town Twinning in Britain Since 1945. Geoforum. (42),115-125.

ÇŞB. (2020). Belediyelere Ait Kardeş Kent İstatistiki Verileri. Çevre ve Şehircilik Bakanlığı: https://www.yerelyonetimler.csb.gov.tr/, Erişim Tarihi: 21.03.2021.

ÇŞB. (2020). Belediyelerin Uluslararası Kuruluş Üyeliklerine İlişkin İstatistikî Veriler. Çevre ve Şehircilik Bakanlığı: https://www.yerelyonetimler.csb.gov.tr/, Erişim Tarihi: 21.03.2021.

Daoudov, M. (2013). Yerel Dış Politikanın Temelleri. İstanbul: Marmara Belediyeler Birliği.

Demirtaş, B. (2016). Türkiye'de Yerel Yönetimlerin Dış İlişkilerinin Analizi: Merkez-Çevre Etkileşimini Yeniden Düşünmek. Uluslararası İlişkiler Dergisi, 13 (52), 151-173.

Eren, E. (2017). "Sivil Toplumun Dış Politika İnşasındaki Rolü: Türk Kamu Diplomasisi Örneği", Ekonomi, Politika \& Finans Araştırmaları Dergisi, 2 (1), 36-49. 
Eren, E. (2018). Balkanlarda Türk Kamu Diplomasisi ve Faaliyet Alanları Yayınlanmamış Yüksek Lisans Tezi. İstanbul: İstanbul Sabahattin Zaim Üniversitesi Sosyal Bilimler Enstitüsü.

Gençkaya, Ö. F. ve K. Kaya (2018). "İstanbul İlçe Belediyelerinin Dış İlişkileri", Uluslararası Yönetim Akademisi Dergisi, 1 (3), 303-316.

GPM. (2021). Global Parliament of Mayors: https://globalparliamentofmayors.org/, Erişim Tarihi: 20.03.2021.

İBB. (2020). İstanbul'un Kardeş Şehir, İşbirliği Protokolleri Ve Mutabakat Zaptı/İyi Niyet Mektupları. İstanbul Büyükşehir Belediyesi: https://www.ibb.istanbul/SitePage/Index/151, Erişim Tarihi: 21.03.2021.

İBB. (2017). İstanbul'dan Kardeş Şehir Odessa'ya 30 Otobüs Hediye. İstanbul Büyükşehir Belediyesi: https://www.ibb.istanbul/News/Detail/34020, Erişim Tarihi: 21.03.2021.

MBB. (2018). Yerel Diplomasi. Marmara Belediyeler Birliği: http://marmara.gov.tr/Yerel-Diplomasi-7688, Erişim Tarihi: 21.03.2021.

Mcmillan, S. L. (2008). Subnational Foreign Policy Actors: How and Why Governors Participate in US Foreign Policy. Foreign Policy Analysis , 4 (3), 232-237.

Mevzuat. (1969). 1173 Sayılı Milletlerarası Münasebetlerin Yürütülmesi ve Koordinasyonu Hakkında Kanun. Mevzuat: https://mevzuat.gov.tr/MevzuatMetin/1.5.1173.pdf, Erişim Tarihi: 21.03.2021.

Mevzuat. (2005). 5393 Sayılı Belediye Kanunu. Mevzuat: https://mevzuat.gov.tr/mevzuatmetin/1.5.5393.pdf, Erişim Tarihi: 21.03.2021.

Mevzuat. (2005). İçişleri Bakanlığı 07.04.2005 tarihli ve 2005/36 Sayılı Genelge. Mevzuat: https://docplayer.biz.tr/21370454-T-c-icisleri-bakanligi-mahalli-idareler-genel-mudurlugu-sayib050mah0650002-865-80970-7-4-2005-genelge-2005-36-valiligine.html, Erişim Tarihi: 21.03.2021.

Ogawa, A. (2012). Sister City As A Preservation Strategy, http://academiccommons.columbia.edu/download/fedora_content/download/ac:147524/CONTENT/_Asuka_Ogawa_Thesis_Sister_City_as_a_Preservation_Strategy_May_2012.pdf, Erişim Tarihi: 08.05.2021.

Özlü, R. M. (2020). "Türk Yerel Yönetimlerinin Uluslar arası İşbirlikleri", İstanbul Medipol Üniversitesi Hukuk Fakültesi Dergisi, 7 (1), 159-189.

Pluijm, R. v., \& Melissen, J. (2007). City Diplomacy: The Expanding Role of Cities in International Politics. Clingendael: Netherlands Institute of International Relations. 
Purtaş, F. (2013). Türk Dış Politikasının Yükselen Değeri: Kültürel Diplomasi. Gazi Üniversitesi Akademik Bakış Dergisi, 7 (13), 1-14.

Ramasamy, B.ve Cremer, R. (1998). Cities, Commerce and Culture: The Economic Role of International Sister-City Relationships between New Zealand and Asia, Journal of the Asia Pacific Economy, Vol. 3, No. 3. January, s. 446-461

Rosenau, J. N. (1995). Governance in the Twenty-First Century. Global Governance , 1 (1), 13-43.

Sister Cities InternationalMeasures That Matter ${ }^{\mathrm{SM}}$ - The Economic Impact Study, (2014-2015). https://sistercities.org/wp-content/uploads/2018/04/Measures-that-Matter.pdf, Erişim Tarihi: 07.05 .2021

TBB. (2018). İstatistiki Veriler. Türkiye Belediyeler Birliği: http://www.yereldiplomasi.gov.tr/kardessehirler-istatistiki-veriler/, Erişim Tarihi: 21.03.2021.

TBB. (2018). Kardeş Ariyorum. Yerel Diplomasi: http://www.yereldiplomasi.gov.tr/kardes-ariyorum-tr/, Erişim Tarihi: 21.03.2021.

TBB. (2018). Kardeş Şehir. Yerel Diplomasi: http://www.yereldiplomasi.gov.tr/kardes-sehir/, Erişim Tarihi: 21.03.2021.

TBB. (2019). Türkiye'de Şehir Eşleştirme Kitapçığı. Yerel Diplomasi: http://www.yereldiplomasi.gov.tr/wpincludes/images/media/turkiye_de_sehir_eslestirme_kitapcigi.pdf, Erişim Tarihi: 21.03.2021.

UCLG. (2020). http://www.uclg.org/en/organisation/about, Erişim Tarihi: 21.03.2021.

Yaylı, H. ve Y. C. Gönültaş (2018). "Uluslararasılaşan Yerel Yönetimler: Yerel Dış Politika (Paradiplomasi) Kavramına Teorik Bir Bakış”, Ankara Hacı Bayram Veli Üniversitesi İktisadi ve İdari Bilimler Fakültesi Dergisi, 20 (2), 271-288. 